\title{
Blue-emitting copper nanoparticles as a fluorescent probe for detection of cyanide ions
}

\author{
Safieh Momeni ${ }^{\mathrm{a}, *}$, Raheleh Ahmadi ${ }^{\mathrm{b}}$, Afsaneh Safavi ${ }^{\mathrm{b}}$, Iraj Nabipour ${ }^{\mathrm{a}}$ \\ a Persian Gulf Marine Biotechnology Research Center, The Persian Gulf Biomedical Sciences Research Institute, Bushehr University of Medical Sciences, \\ Bushehr 75147, Iran \\ b Department of Chemistry, College of Sciences, Shiraz University, Shiraz 71454, Iran
}

\section{A R T I C L E I N F O}

\section{Keywords:}

Ascorbic acid

Copper nanoparticles

Cyanide

Fluorescence

Sensor

\begin{abstract}
A B S T R A C T
A simple and green method for the determination of cyanide ions $\left(\mathrm{CN}^{-}\right)$has been developed which is based on copper nanoparticles (CuNPs) acting as a fluorescent probe in aqueous solutions. In this study, fluorescent CuNPs have been synthesized in the presence of ascorbic acid which acts both as a reducing and protecting agent. The preparation of CuNPs by this method is very simple, low cost, high yield, and reproducible. The prepared CuNPs have the small average diameter of $10 \mathrm{~nm}$ and show a blue emission at $440 \mathrm{~nm}$. However, upon the addition of $\mathrm{CN}^{-}$into the CuNPs sensing system, its fluorescence was quenched considerably as a result of the strong interaction between cyanide and copper. Under optimized conditions, a good relationship was observed between the fluorescence quenching of the system and the concentration of $\mathrm{CN}^{-}$in the range of $0.5-18 \mu \mathrm{mol} \mathrm{L}$ with a detection limit of $0.37 \mu \mathrm{mol} \mathrm{L} \mathrm{L}^{-1}$. In addition, the developed sensor has a high selectivity and simple operations. Furthermore, as a cost-effective and selective fluorescent probe, the CuNPs sensor was successfully employed for the detection of $\mathrm{CN}^{-}$ions in water samples.
\end{abstract}

\section{Introduction}

As a new class of fluorescent probes, fluorescent nanostructures including $\mathrm{Ag}, \mathrm{Au}, \mathrm{Cu}$ nanoclusters (NCs) and $\mathrm{Cu}$ nanoparticles (NPs) have attracted much attention in the past decade as promising substitutes to traditional organic fluorescent dyes and quantum dots $[1,2]$. Fluorescent nanomaterials have unique physical, chemical, and optical properties including excellent photostability, low toxicity, satisfactory water solubility, and good biocompatibility. Compared to fluorescent noble metal NPs, copper nanostructures (NCs or NPs) are better fluorescent probes due to their catalytic activity, high electrical conductivity, and much lower cost [3]. It is important to mention that compared to noble metals, $\mathrm{Cu}$ has an easy oxidation in air which limits its synthesis process and makes it fairly unstable in aqueous solutions. Consequently, for synthesis of water soluble $\mathrm{Cu}$ nanostructures (NCs or NPs) and avoiding their oxidation, many reduction processes have been performed in the presence of different reagents such as biomolecule reagents including DNA [4-6], DNA-RNA heteroduplexes [7], proteins [8] and so on. These reagents act as template, stabilizer, and protective agents for protecting $\mathrm{Cu}$ atoms against oxidation improving the water solubility of $\mathrm{Cu}$ nanostructures.

Among these biomolecule reagents, random double strand DNA
(dsDNA) was employed as an excellent template for the synthesis of CuNPs and CuNCs with good fluorescence, whereas random single strand DNA (ssDNA) template did not support CuNPs formation [9]. DsDNA template CuNPs have been widely used for detection of various targets such as metal ions [10,11], sulfide [12], microRNA [13], Lhistidine [14], exonuclease III [15], nuclease enzyme [16] and ATP [6]. Recently, a single strand polythymine (poly T) was also used as an efficient template for the synthesis of fluorescent CuNPs and the fluorescence intensity of the prepared CuNPs was regulated by the length of poly $\mathrm{T}$ [17]. Poly T-CuNPs have been applied for the construction of trypsin assay [18], and nuclease assay [19]. They also detect various targets such as hydrogen peroxide [20], protein [21], $\mathrm{NAD}^{+}$[22], and DNA [23]. Among the proteins, bovine serum albumin $[24,25]$ and lysozyme [26] have been preferred as stabilizers for the formation of fluorescent CuNCs. The biomolecules such as DNA and proteins that are used in the formation of CuNPs contain rich hydrophilic groups and often lack a rich functional group which greatly limits their applications.

Other kinds of reagents that are used for preparation of $\mathrm{Cu}$ nanostructures are the functional reagents of small molecules such as glutathione [27,28], mercaptobenzoic acids [29], D-penicillamine [30], L-cysteine [31], histidine [32] and polymers (like polyethyleneimine)

\footnotetext{
* Corresponding author.

E-mail address: safieh.momeni@gmail.com (S. Momeni).
} 
$[33,34]$. Furthermore, the presence of particular functional groups on the structure of these reagents can provide spatial interactions in their applications. However, recent reports indicate that CuNCs could be synthesized without the addition of protective reagents and compounds such as penicillamine [35] and ascorbic acid [36] which could be used both as capping and reducing agents.

Cyanide is one of the most toxic materials in the world and is potentially harmful to human beings and other living organisms. The high human toxicity potential of cyanide is related to its propensity to inactivate cytochrome oxidase of the mitochondrial and suppress the transport of oxygen resulting in hypoxia and death of human beings [37]. The permissible limit of cyanide concentration in drinking water which is regulated by the world health organization (WHO) is $1.9 \mu \mathrm{mol} \mathrm{L}{ }^{-1}$. The design and construction of a detection system for selective sensing of cyanide ions $\left(\mathrm{CN}^{-}\right)$has gained great attention because $\mathrm{CN}^{-}$is extremely utilized in many industries such as extraction of silver and gold [38], electroplating metallurgy, and plastic manufacturing [39]. Consequently, the risk of contamination of water sources increases by accidental release of cyanide from these industries to the environment. Accordingly, the selective recognition and quantification of $\mathrm{CN}^{-}$by developing efficient sensors are highly necessary.

Due to the great need to $\mathrm{CN}^{-}$analysis, various analytical methods including electrochemical [40], chromatographic [41], flow injection [42] and spectroscopic methods [43] have been employed for the determination of $\mathrm{CN}^{-}$. Due to their high sensitivity and selectivity, lowcost portability, and ease of operation, fluorescent methods have attracted much attention for the analysis of $\mathrm{CN}^{-}$[43]. The design of fluorescent probes for $\mathrm{CN}^{-}$detection generally relies on different chemical reaction mechanisms such as hydrogen bonding motifs [44], nucleophilic addition [45], supramolecular self-assembly [46], electron-deficient alkene [47] and so on. However, most of these probes have a poor solubility in aqueous solutions and have complicated synthetic procedures and low selectivity for detection of $\mathrm{CN}^{-}$. Consequently, developing an efficient, sensitive, low-cost, and water soluble fluorescent probe for the detection of $\mathrm{CN}^{-}$is essential. Among various probes for the detection of $\mathrm{CN}^{-}$, nanoparticle-based optical sensors are especially attractive [48-57]. In the presence of oxygen, $\mathrm{CN}^{-}$could react with metals such as $\mathrm{Au}$ and $\mathrm{Ag}$ and produce a soluble metal-cyanide complex [49-51]. This well-known reaction has been used to develop a fluorescent probe for $\mathrm{CN}^{-}$detection based on functionalized $\mathrm{Au}$ NPs [48]. The results showed that the fluorescence of water soluble Au nanoclusters stabilized with different compounds such as BSA [49], lysozyme [50], and L-amino acid oxidase [51] was quenched in the presence of $\mathrm{CN}^{-}$, providing a route for $\mathrm{CN}^{-}$sensing. In addition, semiconductor nanoparticles or quantum dots (QDs) such as ZnS [52], CdTe [53] and CdSe NPs [54] have been developed extensively as a fluorescent probe for sensing of $\mathrm{CN}^{-}$. Turn-on fluorescence sensors including dinuclear copper chemosensor [55], carbon quantum dots [56], and graphitic carbon (IV) nitride [57] have been developed for the detection of $\mathrm{CN}^{-}$. In these sensors, the fluorescence of probes is quenched in the presence of $\mathrm{Cu}^{2+}$ ions. Due to the high affinity of copper to $\mathrm{CN}^{-}$, the fluorescence of these probes is turned on in the presence of $\mathrm{CN}^{-}$.

This study focuses on the synthesis of high yield fluorescent CuNPs with only ascorbic acid as stabilizer, protective, and reducing agent without using additional reagents. The preparation of CuNPs by this method is very simple, low cost, high yield and reproducible. The resulting CuNPs with an average particle size of $10 \mathrm{~nm}$ has a good fluorescence, high stability, and dispersibility in aqueous media. The as-prepared CuNPs show blue fluorescence with peaking center at $450 \mathrm{~nm}$. In the presence of $\mathrm{CN}^{-}$, the fluorescence of the as-prepared CuNPs solution is quenched providing the possibility to detect $\mathrm{CN}^{-}$ while other ions cannot cause any interference. Thus, CuNPs have been utilized as a cost-effective and selective fluorescent probe for the detection of $\mathrm{CN}^{-}$in water samples.

\section{Experimental}

\subsection{Chemicals and materials}

Copper sulfate $\left(\mathrm{CuSO}_{4}\right)$, ascorbic acid, sodium hydroxide $(\mathrm{NaOH})$, sodium cyanide $(\mathrm{NaCN})$, Tris- $\mathrm{HCl}$ buffer, acetic acid, boric acid, disodium hydrogen phosphate $\left(\mathrm{Na}_{2} \mathrm{HPO}_{4}\right)$, and sodium dihydrogen phosphate $\left(\mathrm{NaH}_{2} \mathrm{PO}_{4}\right)$ were obtained from Merck. All chemicals and reagents were of analytical grade and used as received without further purification. Four different buffering systems including phosphate buffer (PBS), borate buffer, Britton-Robinson buffer (BRB) and Tris$\mathrm{HCl}$ buffer were used in this study. Deionized water was used for preparation of all stocks and buffer solutions.

\subsection{Apparatus}

Fluorescence measurements were recorded on a spectroflourometer (Perkin Elmer, LS-50B) with excitation and emission slit widths of $10 \mathrm{~nm}$. Excitation wavelength was set at $360 \mathrm{~nm}$ and the fluorescence emission spectra were collected from 380 to $600 \mathrm{~nm}$. The absorbance measurements were made using a Shimadzu 1601 PC UV-vis spectrophotometer. Transmission electron microscopy (TEM) was carried out by using an electronic microscope (Philips F20-200 kV) while FTIR spectra were measured by a Shimadzu FTIR- 8300 series spectrometer in the range of $4000-400 \mathrm{~cm}^{-1}$. A dynamic light scattering (DLS) particle size analyzer (Horiba LB-550) was used to determine the distribution of the particle sizes. X-Ray photoelectron spectroscopy (XPS) measurement was performed by a Thermo Scientifi, ESCALAB $250 \mathrm{Xi} \mathrm{Mg} \mathrm{X-ray} \mathrm{resource.} \mathrm{All} \mathrm{measurements} \mathrm{were} \mathrm{performed} \mathrm{at} \mathrm{room}$ temperature.

\subsection{Synthesis of fluorescent CuNPs}

In a typical preparation method, a solution of $\mathrm{CuSO}_{4}(32 \mathrm{mg})$ and $\mathrm{NaOH}\left(2 \mathrm{~mL}, 0.5 \mathrm{~mol} \mathrm{~L}^{-1}\right)$ in $20 \mathrm{~mL}$ water was stirred for $2 \mathrm{~min}$ and then $20 \mathrm{~mL}$ of $0.1 \mathrm{~mol} \mathrm{~L}^{-1}$ ascorbic acid was added to the mixture and stirred for $10 \mathrm{~min}$ at $50^{\circ} \mathrm{C}$. The color of the solution was changed from yellow to dark pink. Then, $\mathrm{NaOH}$ solution $\left(4 \mathrm{~mL}\right.$ of $0.5 \mathrm{~mol} \mathrm{~L}^{-1}$ ) was added to the above solution to adjust the $\mathrm{pH}$ to 8.0-9.0 and was allowed to react for $15 \mathrm{~h}$ at $50{ }^{\circ} \mathrm{C}$. The final color change of the solution was from dark pink to transparent greenish brown without any precipitate. This CuNPs solution can be stable for at least 2 months when stored at $4{ }^{\circ} \mathrm{C}$.

\subsection{Fluorescence detection of cyanide ions}

In order to use CuNPs as a fluorescent sensor for $\mathrm{CN}^{-}$determination, $2.0 \mathrm{~mL}$ of aqueous solution of borate buffer with $\mathrm{pH} 9.0$ was placed in a quartz cell $(3.0 \mathrm{~cm} \times 1.0 \mathrm{~cm} \times 1.0 \mathrm{~cm})$. Then, $6.0 \mu \mathrm{L}$ of the synthesized CuNPs was added to the buffer and the solution was titrated with consecutive additions of stock solutions of $\mathrm{CN}^{-}$. The fluorescence spectra were recorded after incubating the measured solution for $5 \mathrm{~min}$ at excitation wavelength of $360 \mathrm{~nm}$, scan speed of $500 \mathrm{~nm} \mathrm{~min}^{-1}$.

\subsection{Real sample analysis}

River water, as an aqueous environmental sample with a complex matrix, was employed to evaluate the CuNPs-based fluorescent sensor for sensing of $\mathrm{CN}^{-}$. The water sample was collected from Jam River, Asaluyeh, Iran. $\mathrm{CN}^{-}$was spiked to the river water sample. A standard addition method was used to determine $\mathrm{CN}^{-}$concentration. Determination of $\mathrm{CN}^{-}$in the water sample was carried out by two different procedures including fluorometric determination by synthesized CuNPs and the polarography standard method (DIN38405 part 13). 

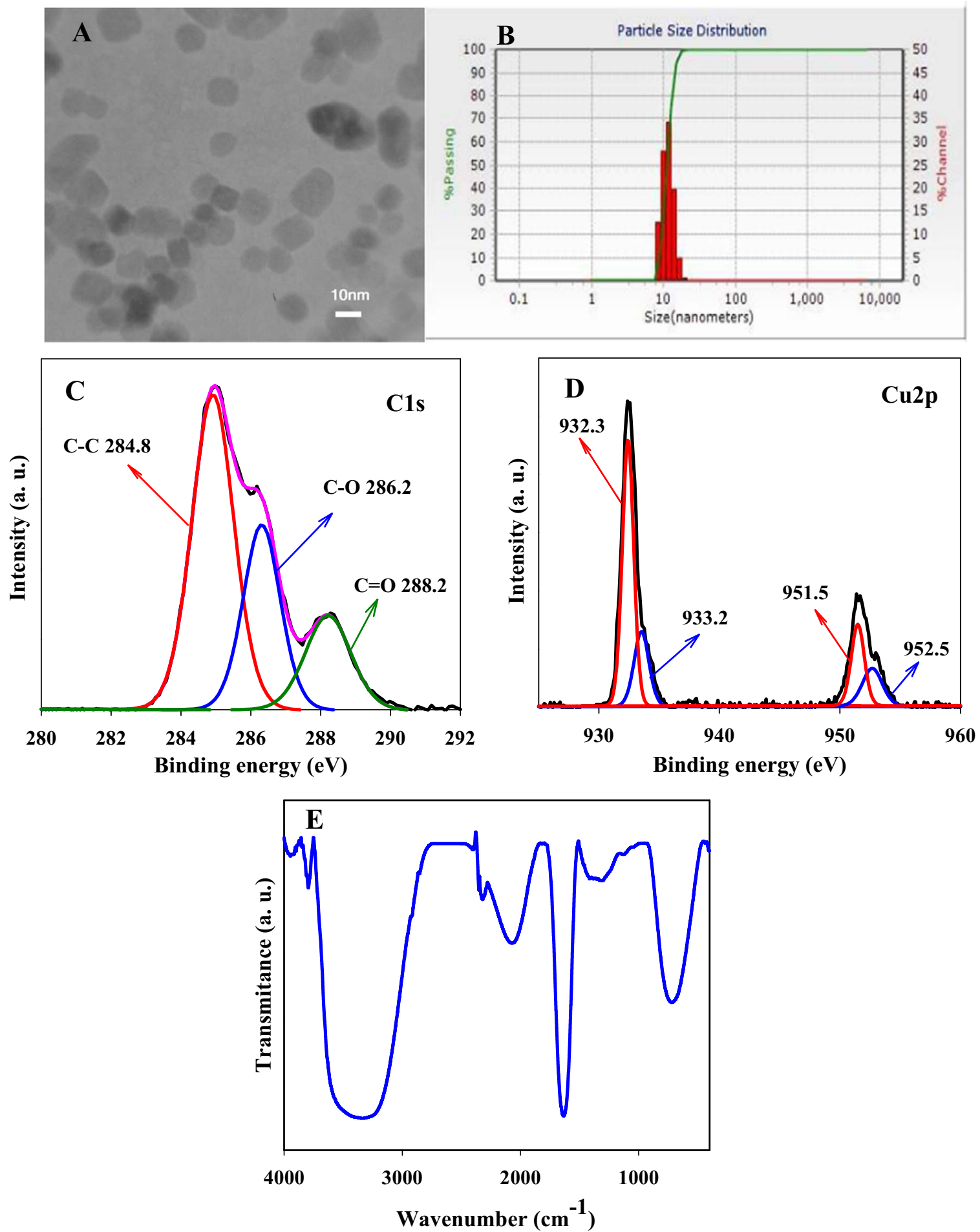

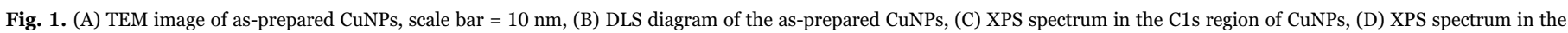
$\mathrm{Cu} 2 \mathrm{p}$ region of CuNPs and (E) FTIR spectrum of the CuNPs.

\section{Results and discussion}

\subsection{Characterization of CuNPs}

In this study, fluorescent and water soluble CuNPs were synthesized by a simple, green, and cheap method. Generally, the reduction and stabilization of copper ions with ascorbic acid in aqueous solutions result in the preparation of a high-yield fluorescent CuNPs without the addition of any others capping ligands. Ascorbic acid is an environmentally-friendly, protecting, capping, and stabilizing agent. The as- prepared CuNPs were characterized by TEM, DLS, UV-vis absorption spectroscopy, fluorescence spectroscopy, XPS, and FTIR spectroscopy. Size information of CuNPs was investigated by TEM and DLS analyses. The TEM image of CuNPs is shown in Fig. 1A. The TEM image shows that CuNPs are highly dispersed and spherical in shape and their average particle size is about $10 \mathrm{~nm}$. To further confirm this, a DLS analysis was performed (Fig. 1B). DLS results demonstrate that the particle size distribution of CuNPs is in the narrow range of 9-12 nm with the average particle size of $10 \mathrm{~nm}$.

The analysis of X-ray photoelectron spectroscopy was used to 
determine the oxidation state of copper in the CuNPs. The high resolution C1s XPS spectrum manifested three peaks (Fig. 1C). The peaks located at $284.8,286.1$, and $288.2 \mathrm{eV}$ can be assigned to $\mathrm{C}-\mathrm{C}, \mathrm{C}-$ $\mathrm{O}$, and $\mathrm{C}^{=} \mathrm{O}$ species, respectively [30]. The XPS spectrum of CuNPs is shown in Fig. 1D. On the Cu2p XPS spectrum there are two prominent peaks classified as the $\mathrm{Cu} 2 \mathrm{p}_{3 / 2}$ and $\mathrm{Cu} 2 \mathrm{p}_{1 / 2}$ at energy levels near to 932 and $952 \mathrm{eV}$, respectively. The peak fit of the $\mathrm{Cu} 2 \mathrm{p}_{3 / 2}$ revealed two binding energy states at 932.1 and $933.2 \mathrm{eV}$. The appearance of splitting in two peaks of $\mathrm{Cu} 2 \mathrm{p}_{3 / 2}$ region indicates that CuNPs consists of two phases of $\mathrm{Cu}$ (two valence states that correspond to $\mathrm{Cu}(0)$ and $\mathrm{Cu}(1+)$ states, respectively). Further, the $\mathrm{Cu} 2 \mathrm{p}_{1 / 2}$ peaks deconvoluted at 951.9 and $952.8 \mathrm{eV}$. In the spectrum, no peak was observed at $942 \mathrm{eV}$ which confirmed that the prepared CuNPs did not contain $\mathrm{Cu}^{2+}$. In addition, the core-level peak-peak difference between $\mathrm{Cu} 2 \mathrm{p}_{3 / 2}$ and $\mathrm{Cu} 2 \mathrm{p}_{1 / 2}$ region was $19.7 \mathrm{eV}$ which confirmed the presence of $\mathrm{Cu}(0) /$ $\mathrm{Cu}(1+)$ form only [58]. Therefore, based on this analysis, it can be concluded that the copper present in CuNPs is in the form of $\mathrm{Cu}(0)$ and $\mathrm{Cu}(1+)$.

The FTIR spectrum of CuNPs was measured to explore the surface groups of CuNPs and the results are shown in Fig. 1E. The FTIR spectrum showed a characteristic adsorption band of O-H stretching vibration at $3334 \mathrm{~cm}^{-1}$. The peaks at 1633 and $1333 \mathrm{~cm}^{-1}$ could be attributed to the characteristic adsorption of $\mathrm{C}^{=} \mathrm{C}$ double bond and enol-hydroxyl stretching vibration, respectively [59]. These results indicated the presence of ascorbic acid as a capping agent on the surface of CuNPs.

The optical characterization of the synthesized CuNPs was performed and the results are shown in Fig. 2A. The absorption spectra of CuNPs indicate a continuous absorption in the UV region, with an
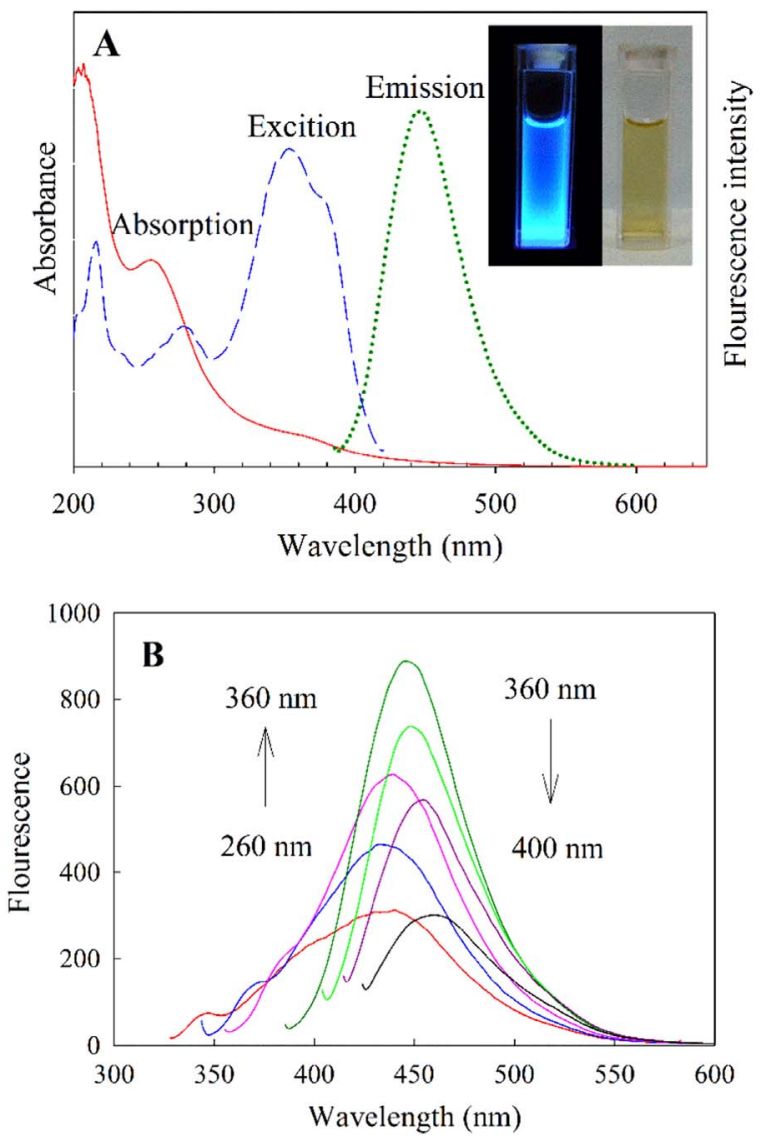

Fig. 2. (A) UV-vis absorption and fluorescence emission and excitation spectra of the aqueous dispersion of CuNCs. Inset: the photographs of CuNCs under (right) daylight and (left) a $365 \mathrm{~nm}$ UV lamp. (B) Fluorescence spectra of the CuNCs at different excitation wavelengths from 260 to $400 \mathrm{~nm}$. extended tail to the visible range. The prepared aqueous solution of CuNPs appeared as greenish brown and transparent under daylight, while under a $365 \mathrm{~nm}$ UV excitation it had a bright blue emission (the inset pictures in Fig. 2A). The synthesized CuNPs exhibited an excitation-dependent fluorescent behaviour (Fig. 2B), like most fluorescent nanoparticles. The maximum fluorescence emission of CuNPs was achieved at $440 \mathrm{~nm}$ when excited by the wavelength of $360 \mathrm{~nm}$. The synthesized CuNPs demonstrated a relatively narrow and symmetric emission band which confirmed its homogeneity and monodispersity. The fluorescence quantum yield of CuNPs was determined to be $1.6 \%$ compared with the known quantum yield of Quinine Sulfate (58\%) at $\lambda_{\mathrm{ex}}=360 \mathrm{~nm}$.

Due to the environmental toxicity or biological hazards that are associated with chemical synthesis, the development of a green synthesis of nanoparticles is required. According to green chemistry principles, the use of cheap, nontoxic chemicals, renewable materials, and environmentally-friendly solvents are some of the essential issues in the nanomaterials synthetic strategy. It is well-known that the reaction medium, capping and reducing agents are three key factors for the synthesis of metal nanoparticles. To date, some expensive and/or toxic capping agents (DNA, proteins, mercaptobenzoic acid, Polyethyleneimine etc.) have been employed to prepare fluorescent CuNPs. Moreover, strong and hazardous reducing agents such as hydrazine, sodium borohydride $\left(\mathrm{NaBH}_{4}\right)$ and dimethylformamide (DMF) have been used in CuNPs synthesis and often produced potential environmental and biological risks. Table 1 shows a comparison between our synthesis method and previously reported methods. In this work, we have developed a green chemical method for the synthesis of CuNPs with ascorbic acid without using any organic solvent or capping agent. Ascorbic acid was used as a green capping and reducing agent in the synthesis process.

\subsection{Sensing application of CuNPs}

The green synthesis fluorescent CuNPs was used as a facile probe for $\mathrm{CN}^{-}$sensing. Prior to using CuNPs as a fluorescence sensor for determining $\mathrm{CN}^{-}$, evaluating the influential factors on the sensitivity of the sensor (such as response time and $\mathrm{pH}$ value of the sensing system) is essential. To investigate the response rate of CuNPs-based fluorescence sensor to $\mathrm{CN}^{-}$, the time-dependent fluorescence signals of the sensor were monitored after adding $10 \mu \mathrm{mol} \mathrm{L}^{-1}$ of $\mathrm{CN}^{-}$(Fig. 3A). As

Table 1

Comparison of different methods for synthesis of fluorescent copper nanostructures.

\begin{tabular}{|c|c|c|c|c|}
\hline Cu nanostructures & Capping agent & $\begin{array}{l}\text { Reducing } \\
\text { agent }\end{array}$ & $\begin{array}{l}\text { Excitation/ } \\
\text { emission } \\
\text { (nm) }\end{array}$ & Ref. \\
\hline CuNCs & Tannic acid & $\begin{array}{l}\text { Ascorbic } \\
\text { acid }\end{array}$ & $360 / 430$ & {$[61]$} \\
\hline CuNPs & ds-DNA & $\begin{array}{l}\text { Ascorbic } \\
\text { acid }\end{array}$ & $340 / 580$ & {$[16]$} \\
\hline CuNPs & Poly (thymine) & $\begin{array}{l}\text { Ascorbic } \\
\text { acid }\end{array}$ & $345 / 630$ & [17] \\
\hline CuNCs & Lysozyme & Hydrazine & $360 / 450$ & {$[26]$} \\
\hline CuNCs & Polyethyleneimine & Hydrazine & $355 / 480$ & {$[33]$} \\
\hline CuNCs & BSA & Hydrazine & $524 / 625$ & {$[24]$} \\
\hline CuNCs & $\begin{array}{l}\text { Mercaptobenzoic } \\
\text { acid }\end{array}$ & - & $338 / 420$ & [29] \\
\hline CuNPs & D-penicillamine & DMF & $326 / 580$ & [35] \\
\hline CuNCs & BSA & $\mathrm{H}_{2} \mathrm{O}_{2}$ & $320 / 420$ & {$[62]$} \\
\hline CuNCs & $\begin{array}{l}\text { Lipoic acid/ } \\
\text { Polyethylneglycole }\end{array}$ & $\mathrm{NaBH}_{4}$ & $320 / 416$ & {$[63]$} \\
\hline CuNCs & Egg white & Hydrazine & $344 / 600$ & {$[64]$} \\
\hline CuNCs & Histidine & - & $350 / 456$ & {$[32]$} \\
\hline CuNCs & Trypsin & - & $370 / 455$ & {$[65]$} \\
\hline CuNCs & Glutathione & - & $360 / 445$ & {$[27]$} \\
\hline CuNPs & Ascorbic acid & - & $360 / 440$ & $\begin{array}{l}\text { This } \\
\text { work }\end{array}$ \\
\hline
\end{tabular}




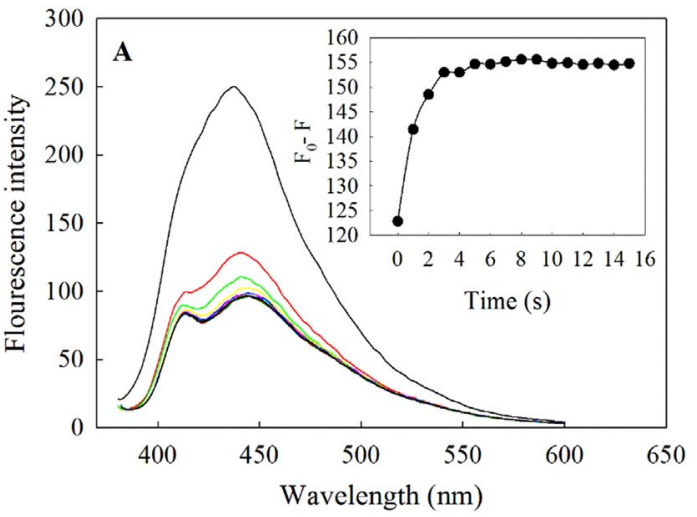

B

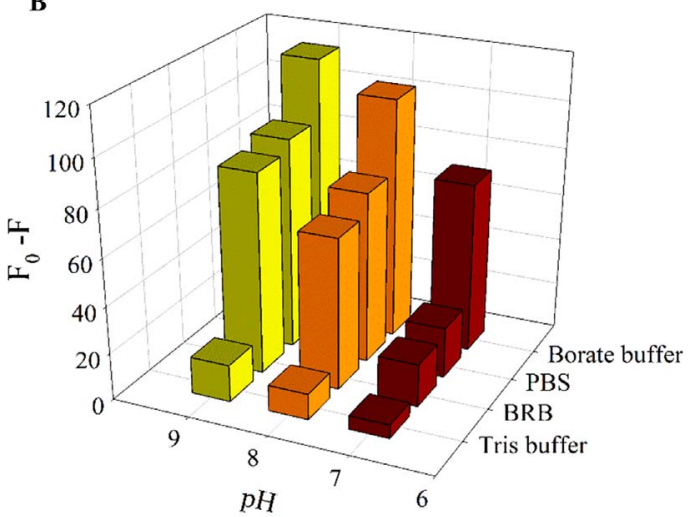

Fig. 3. (A) Time-dependent fluorescence response of the CuNPs to $10 \mu \mathrm{mol} \mathrm{L}-1 \mathrm{CN}^{-}$. The inset shows $\mathrm{F}_{0}-\mathrm{F}$ plotted against time in the presence of $10 \mu \mathrm{mol} \mathrm{L}^{-1} \mathrm{CN}^{-}$where $\mathrm{F}_{0}$ and $\mathrm{F}$ are the fluorescence intensity of CuNPs in the absence and presence of $\mathrm{CN}^{-}$, respectively. (B) $\mathrm{F}_{0}-\mathrm{F}$ plotted against $\mathrm{pH}$ and type of buffer in the presence of $10 \mu \mathrm{mol} \mathrm{L}-1 \mathrm{CN}^{-}$.

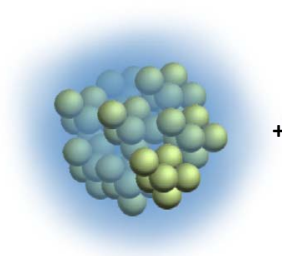

CuNPs

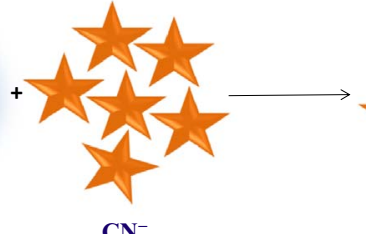

$\mathrm{CN}^{-}$

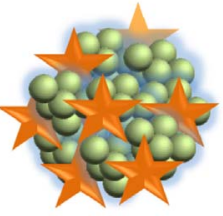

Scheme 1. The mechanism of fluorescence quenching of CuNPs by $\mathrm{CN}^{-}$.

observed in Fig. 3A, the fluorescence intensity of CuNPs at $440 \mathrm{~nm}$ was quenched by $\sim 60 \%$ within 1 min and remained constant after 5 min. Therefore, $5 \mathrm{~min}$ was selected as an optimized time to measure the response of the CuNPs-based fluorescence sensor to $\mathrm{CN}^{-}$.

As is well-known, $\mathrm{CN}^{-}$can combine strongly with copper ions to produce stable $\mathrm{Cu}(\mathrm{CN})_{\mathrm{x}}{ }^{\mathrm{n}-}$ species (generally $\mathrm{Cu}(\mathrm{CN})_{2}{ }^{-}$and $\mathrm{Cu}(\mathrm{CN})_{4}{ }^{3-}$ species with stability constants of $1.00 \times 10^{24}$ and $2.00 \times 10^{30}$, respectively) [60]. As mentioned above, the copper present in the structure of CuNPs is in the form of $\mathrm{Cu}(0)$ and $\mathrm{Cu}(1+)$. Furthermore, the fluorescence quenching can be attributed mainly to chemical interaction between $\mathrm{CN}^{-}$and $\mathrm{Cu}(1+)$ in the structure of CuNPs. It seems that cyanide ions combined strongly with $\mathrm{Cu}(1+)$ in the structure of CuNPs and quenched the fluorescence of the nanoparticles. The probable mechanism of fluorescence quenching of CuNPs by $\mathrm{CN}^{-}$is shown in Scheme 1.

The $\mathrm{pH}$ value of the sensing system was investigated as a crucial factor. Upon excitation with $360 \mathrm{~nm}$ beam, CuNPs shows a strong and stable fluorescence emission peak at $\sim 440 \mathrm{~nm}$ in a $\mathrm{pH}$ range of 7.09.0. Therefore, the influence of the solution $\mathrm{pH}$ on the fluorescence quenching effect of $\mathrm{CN}^{-}$in the $\mathrm{pH}$ range of 7.0-9.0 was investigated.
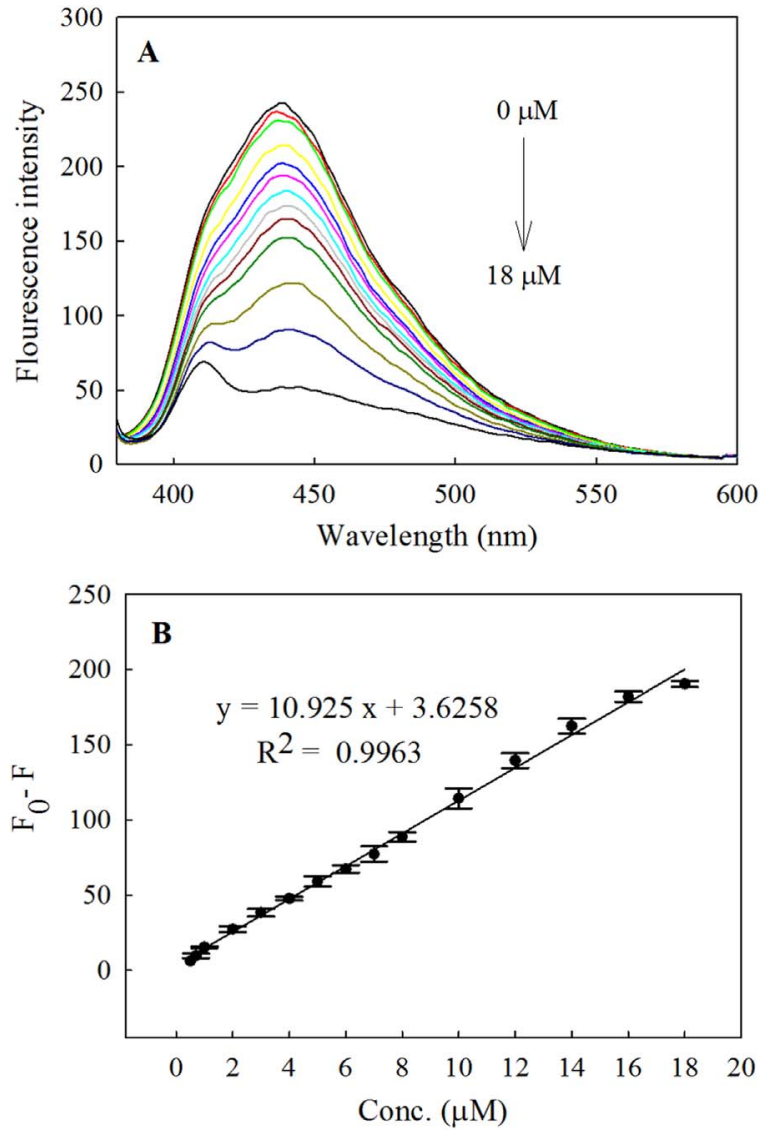

Fig. 4. (A) The fluorescence response of the CuNPs upon addition of various concentrations of $\mathrm{CN}^{-}$at a $\mathrm{pH}$ of 9 (from top: $0-18 \mu \mathrm{mol} \mathrm{L}{ }^{-1}$ ). (B) Calibration curves for $\mathrm{CN}^{-}$(the error bars represent the standard deviation of three measurements).

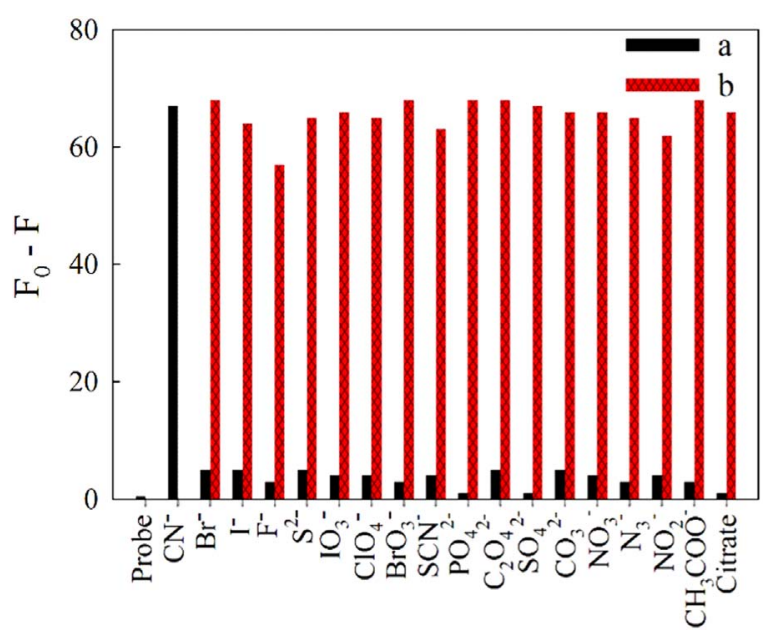

Fig. 5. a) Selectivity of the CuNPs-based fluorescence sensor for $\mathrm{CN}^{-}$over other anions. The concentration of anions is $1 \mathrm{mmol} \mathrm{L}^{-1}$ and $\mathrm{CN}^{-}$concentration is $6 \mu \mathrm{mol} \mathrm{L} \mathrm{L}^{-1}$. b) $\mathrm{F}_{0}$ F plotted against $6 \mu \mathrm{mol} \mathrm{L}^{-1}$ of $\mathrm{CN}^{-}$with the coexistence of other anions at a concentration of $1 \mathrm{mmol} \mathrm{L}^{-1}$.

This pH range was achieved by using four different buffering systems including borate buffer, phosphate buffer (PBS), Britton-Robinson buffer (BRB), and Tris- $\mathrm{HCl}$ buffer (all $0.1 \mathrm{~mol} \mathrm{~L}^{-1}$ ). As observed in Fig. 3B, the change of fluorescence intensity reached its maximum in borate buffer with the $\mathrm{pH}$ of 9.0. Depending on the $\mathrm{pH}$ of the aqueous solution, cyanide may exist in two form including $\mathrm{CN}^{-}$and $\mathrm{HCN}\left(\mathrm{pK}_{\mathrm{a}}=\right.$ 9.36). At the $\mathrm{pH}$ values of $<9.0, \mathrm{HCN}\left(\mathrm{pK}_{\mathrm{a}}=9.36\right)$ is the major form of $\mathrm{CN}^{-}$which interacts weakly with CuNPs. 
Table 2

Assay precision and accuracy of QC samples.

\begin{tabular}{|c|c|c|c|c|c|c|}
\hline & Nominal concentration $\left(\mu \mathrm{mol} \mathrm{L}{ }^{-1}\right)$ & Found concentration $\left(\mu \mathrm{mol} \mathrm{L}{ }^{-1}\right)$ & Accuracy (R\%) (n = 5) & Average of R\% & Precision $(\mathrm{RSD} \%)(\mathrm{n}=5)$ & Average of RSD\% \\
\hline \multirow[t]{3}{*}{ Intra-assay } & 4.00 & 3.90 & 97.50 & 100.61 & 4.43 & 2.57 \\
\hline & 10.00 & 10.09 & 100.90 & & 1.51 & \\
\hline & 14.00 & 14.48 & 103.43 & & 1.76 & \\
\hline \multirow[t]{3}{*}{ Inter-assay } & 4.00 & 3.88 & 97.00 & 100.67 & 4.53 & 4.37 \\
\hline & 10.00 & 10.33 & 103.30 & & 4.70 & \\
\hline & 14.00 & 14.24 & 101.71 & & 3.89 & \\
\hline
\end{tabular}

R: Recovery.

RSD: Relative standard deviation.

Table 3

Results of the evaluation of method robustness in ten different levels.

\begin{tabular}{|c|c|c|c|c|c|c|}
\hline & Level & $\begin{array}{l}\text { Nominal concentration } \\
\left(\mu \mathrm{mol} \mathrm{L}{ }^{-1}\right)\end{array}$ & $\begin{array}{l}\text { Found concentration } \\
\left(\mu \mathrm{mol} \mathrm{L} \mathrm{L}^{-1}\right)\end{array}$ & $\begin{array}{l}\text { Average of found } \\
\text { concentrations }\end{array}$ & Recovery (R\%) & Average of R\% \\
\hline \multirow{10}{*}{$\begin{array}{l}\text { Deliberate variations in the } \\
\text { operational variables }\end{array}$} & 1 & 10.00 & 10.42 & \multirow[t]{10}{*}{10.16} & 104.20 & \multirow[t]{10}{*}{101.56} \\
\hline & 2 & 10.00 & 10.15 & & 101.50 & \\
\hline & 3 & 10.00 & 10.62 & & 106.20 & \\
\hline & 4 & 10.00 & 9.32 & & 93.20 & \\
\hline & 5 & 10.00 & 10.29 & & 102.90 & \\
\hline & 6 & 10.00 & 10.76 & & 107.60 & \\
\hline & 7 & 10.00 & 9.93 & & 99.30 & \\
\hline & 8 & 10.00 & 9.61 & & 96.10 & \\
\hline & 9 & 10.00 & 10.38 & & 103.80 & \\
\hline & 10 & 10.00 & 10.08 & & 100.80 & \\
\hline \multirow[t]{5}{*}{ Optimal conditions } & 11 & 10.00 & 10.21 & \multirow[t]{5}{*}{10.09} & 102.08 & \multirow[t]{5}{*}{100.93} \\
\hline & 12 & 10.00 & 9.88 & & 98.80 & \\
\hline & 13 & 10.00 & 9.97 & & 99.71 & \\
\hline & 14 & 10.00 & 10.18 & & 101.81 & \\
\hline & 15 & 10.00 & 10.22 & & 102.24 & \\
\hline
\end{tabular}

$1: \mathrm{pH}=8.8$, buffer concentration: $0.09 \mathrm{~mol} \mathrm{~L}^{-1}$, response time: $5.2 \mathrm{~min}$.

2: $\mathrm{pH}=8.8$, buffer concentration: $0.11 \mathrm{~mol} \mathrm{~L}^{-1}$, response time: $4.8 \mathrm{~min}$.

3: $\mathrm{pH}=9.0$, buffer concentration: $0.09 \mathrm{~mol} \mathrm{~L}^{-1}$, response time: $4.8 \mathrm{~min}$.

4: $\mathrm{pH}=9.2$, buffer concentration: $0.11 \mathrm{~mol} \mathrm{~L}^{-1}$, response time: $4.8 \mathrm{~min}$.

5: $\mathrm{pH}=9.2$, buffer concentration: $0.09 \mathrm{~mol} \mathrm{~L}^{-1}$, response time: $5.2 \mathrm{~min}$.

6: $\mathrm{pH}=9.0$, buffer concentration: $0.11 \mathrm{~mol} \mathrm{~L}^{-1}$, response time: $5.2 \mathrm{~min}$.

7: $\mathrm{pH}=8.8$, buffer concentration: $0.09 \mathrm{~mol} \mathrm{~L}^{-1}$, response time: $4.8 \mathrm{~min}$.

8: $\mathrm{pH}=9.2$, buffer concentration: $0.11 \mathrm{~mol} \mathrm{~L}^{-1}$, response time: $5.2 \mathrm{~min}$.

9: $\mathrm{pH}=8.8$, buffer concentration: $0.11 \mathrm{~mol} \mathrm{~L}^{-1}$, response time: $5.2 \mathrm{~min}$.

10: $\mathrm{pH}=9.2$, buffer concentration: $0.09 \mathrm{~mol} \mathrm{~L}^{-1}$, response time: $4.8 \mathrm{~min}$.

R: Recovery.

Table 4

Determination of $\mathrm{CN}^{-}$in the river water

\begin{tabular}{|c|c|c|c|}
\hline Sample & $\begin{array}{l}\mathrm{CN}^{-} \text {added } \\
\left(\mu \mathrm{mol} \mathrm{L}^{-1}\right)\end{array}$ & $\begin{array}{l}\mathrm{CN}^{-} \text {found } \\
\text { with developed } \\
\text { method } \\
\left(\mu \mathrm{mol} \mathrm{L}^{-1}\right)( \pm \mathrm{SD})\end{array}$ & $\begin{array}{l}\mathrm{CN}^{-} \text {found } \\
\text { with standard } \\
\text { method } \\
\left(\mu \mathrm{mol} \mathrm{L}^{-1}\right)( \pm \mathrm{SD})\end{array}$ \\
\hline \multirow[t]{7}{*}{ River water } & - & $\mathrm{ND}^{* * *}$ & $\mathrm{ND}^{* * *}$ \\
\hline & 2.00 & $1.97( \pm 0.37)$ & $2.09( \pm 0.03)$ \\
\hline & 4.00 & $3.92( \pm 0.36)$ & $4.01( \pm 0.03)$ \\
\hline & 6.00 & $6.13( \pm 0.12)$ & $6.07( \pm 0.07)$ \\
\hline & 10.00 & $9.95( \pm 0.25)$ & $9.92( \pm 0.10)$ \\
\hline & 12.00 & $12.16( \pm 0.20)$ & $12.03( \pm 0.04)$ \\
\hline & 14.00 & $14.11( \pm .43)$ & $13.96( \pm 0.08)$ \\
\hline
\end{tabular}

* The obtained values are the average of three determinations and the values in the parentheses are the standard deviations.

*** Not detected.

\subsection{Sensitivity and selectivity of the sensing system}

The sensitivity of the CuNPs-based fluorescence sensor for $\mathrm{CN}^{-}$ detection was investigated by adding different concentrations of $\mathrm{CN}^{-}$to a series of CuNPs solutions under optimized conditions. Variation in the fluorescence intensity of the CuNPs was measured after adding different concentrations of $\mathrm{CN}^{-}$in the fixed time of $5 \mathrm{~min}$. As observed in Fig. 4, the fluorescence intensity of the CuNPs at $440 \mathrm{~nm}$ gradually decreased as the concentration of $\mathrm{CN}^{-}$increased. The fluorescence quenching factor, $\mathrm{F}_{0}-\mathrm{F}$, has been plotted against $\mathrm{CN}^{-}$concentration (inset of Fig. 4). $\mathrm{F}_{0}$ and $\mathrm{F}$ display the fluorescence intensity of CuNPs in the absence and presence of $\mathrm{CN}^{-}$, respectively. A good linear relationship was obtained between the fluorescence quenching factor and $\mathrm{CN}^{-}$ concentration over the range of $0.5-18 \mu \mathrm{mol} \mathrm{L}{ }^{-1}$ with correlation coefficient of 0.9963 (inset of Fig. 4). The theoretical detection limit was estimated as $0.37 \mu \mathrm{mol} \mathrm{L} \mathrm{L}^{-1}$, at an $\mathrm{S} / \mathrm{N}$ ratio of 3 . It is $\sim 7$ times lower than the maximum level of $\mathrm{CN}^{-}\left(1.9 \mu \mathrm{mol} \mathrm{L}{ }^{-1}\right)$ in drinking water permitted by the World Health Organization (WHO).

High selectivity is a vital feature of excellent sensors. The selectivity of the CuNPs-based fluorescence sensor for determination of $\mathrm{CN}^{-}$was investigated. This was done by measuring the fluorescence response of this sensor caused by $1 \mathrm{mmol} \mathrm{L}^{-1}$ of seventeen common anions (including citrate, $\mathrm{CH}_{3} \mathrm{COO}^{-}, \mathrm{NO}_{2}{ }^{-}, \mathrm{N}_{3}{ }^{-}, \mathrm{NO}_{3}{ }^{-}, \mathrm{CO}_{3}{ }^{2-}, \mathrm{SO}_{4}{ }^{2-}$, $\mathrm{C}_{2} \mathrm{O}_{4}{ }^{2-}, \mathrm{PO}_{4}{ }^{3-}, \mathrm{SCN}^{-}, \mathrm{BrO}_{3}{ }^{-}, \mathrm{ClO}_{4}^{-}, \mathrm{IO}_{3}{ }^{-}, \mathrm{S}_{2}{ }^{-}, \mathrm{F}^{-}, \mathrm{I}^{-}$and $\mathrm{Br}^{-}$) in the absence and presence of $6 \mathrm{mmol} \mathrm{L}^{-1}$ of $\mathrm{CN}^{-}$under the optimum conditions. As observed in Fig. 5, only $\mathrm{CN}^{-}$caused an intense decrease in the CuNPs fluorescence intensity, whereas, no significant fluorescence changes were observed in the presence of high concentrations of other anions. These results indicate the high selectivity of the CuNPsbased fluorescence sensor toward $\mathrm{CN}^{-}$over other anions.

Intra- and inter-day assay precision and accuracy of the developed 
method were evaluated by analysing five replicates at three different quality control (QC) sample concentrations under optimal experimental conditions. QC samples were prepared at low $\left(4 \mu \mathrm{mol} \mathrm{L}^{-1}\right)$, medium $\left(10 \mu \mu \mathrm{mol} \mathrm{L}{ }^{-1}\right)$, and high $\left(14 \mu \mathrm{mol} \mathrm{L}^{-1}\right)$ concentrations of $\mathrm{CN}^{-}$and were analysed on the same day (intra-day assay) and on five different days (inter-day assay). The results in terms of recovery percentage ( $R$ $\%)$ and relative standard deviation percentage (RSD\%) are summarized in Table 2. The obtained results for these validation experiments confirmed that the developed method is both accurate and precise.

The ability of the developed analytical method against small positive or negative changes in practical effective variables during the operations was assessed by robustness testing. In this regard, small deliberate variations in the operational variables including $\mathrm{pH}( \pm$ $0.2 \mathrm{pH}$ unit), buffer concentration $\left( \pm 0.01 \mathrm{~mol} \mathrm{~L}^{-1}\right)$ and response time of the sensor $( \pm 0.2 \mathrm{~min})$ were introduced and the fluorescence response of the sensor was monitored (Table 3). Negligible differences between the obtained data and optimal conditions revealed the fact that the developed method has a reliable robustness ability.

\subsection{Analytical applications in natural sample}

The feasibility of this method was demonstrated by analysing the water sample. The practical applicability of the CuNPs-based fluorescent sensor was evaluated by sensing $\mathrm{CN}^{-}$in river water as an aqueous environmental sample with a complex matrix. The water sample was collected from Jam River, Asaluyeh, Iran. $\mathrm{CN}^{-}$was spiked to the river water sample. Determination of $\mathrm{CN}^{-}$in water sample was carried out by two different procedures including fluorometric determination by synthesized CuNPs and the polarography standard method (DIN38405 part 13). A standard addition method was used to determine $\mathrm{CN}^{-}$ concentration. The results of recovery experiments are listed in Table 4. The data presented are the average of three determinations by the developed sensor and the polarography standard method. It can be seen that there is a good agreement between the results obtained by the two methods. These results confirm the accuracy and reliability of the CuNPs probe for determination of $\mathrm{CN}^{-}$in the analysis of environmental samples.

\section{Conclusion}

In conclusion, we have developed a simple and green method for synthesis of high yield fluorescent copper nanoparticles with ascorbic acid as both a reducing and capping agent. The prepared CuNPs with an average size of $10 \mathrm{~nm}$ showed a good water dispersibility, bright blue fluorescence $\left(\lambda_{\max }=440 \mathrm{~nm}\right)$, high photostability, and colloidal stability. Moreover, the obtained CuNPs was used as a fluorescent probe to selectively detect $\mathrm{CN}^{-}$in aqueous solutions. However, upon the addition of $\mathrm{CN}^{-}$into the CuNPs sensing system, its fluorescence was quenched considerably. The results indicate that the proposed method shows a good selectivity and sensitivity for the $\mathrm{CN}^{-}$detection. Coupling this efficient fluorescence feature with a simple and green synthesis strategy, these fluorescent nanomaterials possess a great potential for chemical sensing.

\section{Acknowledgments}

The authors wish to express their gratitude to Shiraz University Research Council, for the financial support of this work. This project was partly supported by Iran National Science Foundation (Research Chair Award No. 95/INSF/44913).

\section{References}

[1] J. Li, J.-J. Zhu, K. Xu, Fluorescent metal nanoclusters: from synthesis to applications, Trends Anal. Chem. 58 (2014) 90-98.

[2] L. Zhang, E. Wang, Metal nanoclusters: new fluorescent probes for sensors and bioimaging, Nano Today 9 (2014) 132-157.

[3] X. Hu, T. Liu, Y. Zhuang, W. Wang, Y. Li, W. Fan, Y. Huang, Recent advances in the analytical applications of copper nanoclusters, Trends Anal. Chem. 77 (2016) $66-75$.

[4] X. Jia, J. Li, L. Han, J. Ren, X. Yang, E. Wang, DNA-hosted copper nanoclusters for fluorescent identification of single nucleotide polymorphisms, ACS Nano 6 (2012) 3311-3317.

[5] L. Zhang, J. Zhao, H. Zhang, J. Jiang, R. Yu, Double strand DNA-templated copper nanoparticle as a novel fluorescence indicator for label-free detection of polynucleotide kinase activity, Biosens. Bioelectron. 44 (2013) 6-9.

[6] Z. Zhou, Y. Du, S. Dong, Double-strand DNA-templated formation of copper nanoparticles as fluorescent probe for label-free aptamer sensor, Anal. Chem. 83 (2011) 5122-5127.

[7] Z. Wang, L. Si, J. Bao, Z. Dai, A reusable microRNA sensor based on the electrocatalytic property of hetero duplex templated copper nanoclusters, Chem. Commun. 51 (2015) 6305-6307.

[8] L. Ruiyi, W. Huiying, Z. Xiaoyan, L. Xiaoqing, S. Xiulanb, L. Zaijun, DPenicillamine and bovine serum albumin co-stabilized copper nanoclusters with remarkably enhanced fluorescence intensity and photostability for ultrasensitive detection of $\mathrm{Ag}^{+}$, New J. Chem. 40 (2016) 732-739.

[9] A. Rotaru, S. Dutta, E. Jentzsch, K. Gothelf, A. Mokhir, Selective dsDNA-templated formation of copper nanoparticles in solution, Angew. Chem. Int. Ed. 49 (2010) 5665-5667.

[10] Y. Guo, F. Cao, X. Lei, L. Mang, S. Cheng, J. Song, Fluorescent copper nanoparticles: recent advances in synthesis and applications for sensing metal ions, Nanoscale 8 (2016) 4852-4863.

[11] J. Chen, J. Liu, Z. Fang, L. Zeng, Random dsDNA-templated formation of copper nanoparticles as novel fluorescence probes for label-free lead ions detection, Chem. Commun. 48 (2012) 1057-1059.

[12] J. Liu, J. Chen, Z. Fang, L. Zeng, A simple and sensitive sensor for rapid detection of sulfide anions using DNA-templated copper nanoparticles as fluorescent probes, Analyst 137 (2012) 5502-5505.

[13] F. Xu, H. Shi, X. He, K. Wang, D. He, Q. Guo, Z. Qing, L. Yan, X. Ye, D. Li, J. Tang, Concatemeric dsDNA-templated copper nanoparticles strategy with improved sensitivity and stability based on rolling circle replication and its application in MicroRNA detection, Anal. Chem. 86 (2014) 6976-6982.

[14] H.-B. Wang, H.-D. Zhang, Y. Chen, Y.-M. Liu, Inhibition of double-stranded DNA template copper nanoparticles as label-free fluorescent sensors for L-histidine detection, New J. Chem. 39 (2015) 8896-8900.

[15] H. Zhang, Z. Lin, X. Su, Label-free detection of exonuclease III by using dsDNAtemplate copper nanoparticles as fluorescent probe, Talanta 131 (2015) 59-63.

[16] R. Hu, Y.-R. Liu, R.-M. Kong, M.J. Donovan, X.-B. Zhang, W. Tan, G.-L. Shen, R.Q. Yu, Double-strand DNA-templated formation of copper nanoparticles as fluorescent probe for label free nuclease enzyme detection, Biosens. Bioelectron. 42 (2013) 31-35.

[17] Z. Qing, X. He, D. He, K. Wang, F. Xu, T. Qing, X. Yang, Poly(thymine)-templated selective formation of fluorescent copper nanoparticles, Angew. Chem. Int. Ed. 52 (2013) 9719-9722.

[18] L.-J. Ou, X.-Y. Li, L.-J, Li, H.-W. Liu, A -M. Sun, K.-J. Liu, Sensitive assay of trypsin using poly(thymine)-templated copper nanoparticles as fluorescent probes, Analyst 140 (2015) 1871-1875.

[19] Z. Qing, X. He, T. Qing, K. Wang, H. Shi, D. He, Z. Zou, L. Yan, F. Xu, X. Ye, Z. Mao, Poly(thymine)-templated fluorescent copper nanoparticles for ultrasensitive labelfree nuclease assay and its inhibitors screening, Anal. Chem. 85 (2013) $12138-12143$.

[20] Z. Mao, Z. Qing, T. Qing, F. Xu, L. Wen, X. He, D. He, H. Shi, K. Wang, Poly(thymine)-templated copper nanoparticles as a fluorescent indicator for hydrogen peroxide and oxidase-based biosensing, Anal. Chem. 87 (2015) 7454-7460.

[21] H.-B. Wang, H.-D. Zhang, Y. Chen, Y.-M. Liu, A fluorescent biosensor for protein detection based on poly(thymine)- template copper nanoparticles and terminal protection of small molecule-linked DNA, Biosens. Bioelectron. 74 (2015) $581-586$.

[22] Y. Wang, H. Cui, Z. Cao, C. Lau, J. Lu, Additive and enhanced fluorescence effects of hairpin DNA template-based copper nanoparticles and their application for the detection of NAD ${ }^{+}$, Talanta 154 (2016) 574-580.

[23] W. Hu, Y. Ning, J. Kong, X. Zhang, Formation of copper nanoparticles on poly(thymine) through surface-initiated enzymatic polymerization and its application for DNA detection, Analyst 140 (2015) 5678-5684.

[24] C. Wang, C. Wang, L. Xu, H. Cheng, Q. Lin, C. Zhang, Protein-directed synthesis of $\mathrm{pH}-$ responsive red fluorescent copper nanoclusters and applications in cellular imaging and catalysts, Nanoscale 6 (2014) 1775-1781.

[25] Z. Gao, R. Su, W. Qi, L. Wang, Z. He, Copper nanocluster-based fluorescent sensors for sensitive and selective detection of kojic acid in food stuff, Sens. Actuators B 195 (2014) 359-364

[26] R. Ghosh, A.K. Sahoo, S.S. Ghosh, A. Paul, A. Chattopadhyay, Blue-emitting copper nanoclusters synthesized in the presence of lysozyme as candidates for cell labeling, ACS Appl. Mater. Interfaces 6 (2014) 3822-3828.

[27] X. Hu, W. Wang, Y. Huang, Copper nanocluster-based fluorescent probe for sensitive and selective detection of $\mathrm{Hg}^{2+}$ in water and food stuff, Talanta 154 (2016) 409-415.

[28] C. Wang, H. Cheng, Y. Huang, Z. Xu, H. Lin, C. Zhang, Facile sonochemical synthesis of $\mathrm{pH}$-responsive copper nanoclusters for selective and sensitive detection of $\mathrm{Pb}^{2+}$ in living cells, Analyst 140 (2015) 5634-5639.

[29] Y.-J. Lin, P.-C. Chen, Z. Yuan, J.-Y. Ma, H.-T. Chang, Isomeric effect of mercaptobenzoic acids on the preparation and fluorescent properties of copper 
nanoclusters, Chem. Commun. 51 (2015) 11983-11986.

[30] S.M. Lin, S. Geng, N. Li, N.B. Li, H.Q. Luo, D-penicillamine-templated copper nanoparticles via ascorbic acid reduction as a mercury ion sensor, Talanta 151 (2016) 106-113.

[31] X. Yang, Y. Feng, S. Zhu, Y. Luo, Y. Zhuo, Y. Dou, One-step synthesis and applications of fluorescent $\mathrm{Cu}$ nanoclusters stabilized by L-cysteine in aqueous solution, Anal. Chim. Acta 847 (2014) 49-54.

[32] X.J. Zhao, C.Z. Huang, Water-soluble luminescent copper nanoclusters reduced and protected by histidine for sensing of guanosine $5^{\prime}$-triphosphate, New J. Chem. 38 (2014) 3673-3677.

[33] Y. Ling, N. Zhang, F. Qu, T. Wen, Z.F. Gao, N.B. Li, H.Q. Luo, Fluorescent detection of hydrogen peroxide and glucose with polyethyleneimine-templated $\mathrm{Cu}$ nanoclusters, Spectrochim. Acta A 118 (2014) 315-320.

[34] C. Wang, Y. Yao, Q. Song, Interfacial synthesis of polyethyleneimine-protected copper nanoclusters: size-dependent tunable photoluminescence, $\mathrm{pH}$ sensor and bioimaging, Colloids Surf. B 140 (2016) 373-381.

[35] J.-Y. Ma1, P.-C. Chen, H.-T. Chang, Detection of hydrogen sulfide through photoluminescence quenching of penicillamine-copper nanocluster aggregates, Nanotechnology 25 (2014) 195502-195508.

[36] X.-J. Zheng, R.-P. Liang, Z.-J. Li, L. Zhang, J.-D. Qiu, One-step, stabilizer-free and green synthesis of $\mathrm{Cu}$ nanoclusters as fluorescent probes for sensitive and selective detection of nitrite ions, Sens. Actuators B 230 (2016) 314-319.

[37] F. Wang, L. Wang, X.Q. Chen, J. Yoon, Recent progress in the development of fluorometric and colorimetric chemosensors for detection of cyanide ions, Chem. Soc. Rev. 43 (2014) 4312-4324.

[38] M.A. Acheampong, R.J.W. Meulepas, P.N.L. Lens, Removal of heavy metals and cyanide from gold mine wastewater, J. Chem. Technol. Biotechnol. 85 (2010) 590-613.

[39] C. Young, L. Tidwel, C. Anderson, Cyanide: Social, Industrial and Economic Aspects, Minerals, Metals, and Materials Society; Warrendale, PA, 2001

[40] A. Safavi, N. Maleki, H.R. Shahbaazi, Indirect determination of cyanide ion and hydrogen cyanide by adsorptive stripping voltammetry at a mercury electrode, Anal. Chim. Acta 503 (2004) 213-221.

[41] C. Lacroix, E. Saussereau, F. Boulanger, J.P. Goullé, Online liquid chromatographytandem mass spectrometry cyanide determination in blood, J. Anal. Toxicol. 35 (2011) 143-147.

[42] D.G. Themelis, S.C. Karastogianni, P.D. Tzanavaras, Selective determination of cyanides by gas diffusion-stopped flow-sequential injection analysis and an on-line standard addition approach, Anal. Chim. Acta 632 (2009) 93-100.

[43] Z.C. Xu, X.Q. Chen, H.N. Kim, J. Yoon, Sensors for the optical detection of cyanide ion, Chem. Soc. Rev. 39 (2010) 127-137.

[44] G.J. Park, Y.W. Choi, D. Lee, C. Kim, A simple colorimetric chemosensor bearing a carboxylic acid group with high selectivity for $\mathrm{CN}^{-}$, Spectrochim. Acta A 132 (2014) $771-775$.

[45] S.-T. Wang, Y.-W. Sie, C.-F. Wan, A.-T. Wu, A reaction-based fluorescent sensor for detection of cyanide in aqueous media, J. Lumin. 173 (2016) 25-29.

[46] B. Shi, P. Zhang, T. Wei, H. Yao, Q. Lin, Y. Zhang, Highly selective fluorescent sensing for $\mathrm{CN}^{--}$in water: utilization of the supramolecular self-assembly, Chem. Commun. 49 (2013) 7812-7814.

[47] X. Cheng, R. Tang, H. Jia, J. Feng, J. Qin, Z. Li, New fluorescent and colorimetric probe for cyanide: direct reactivity, high selectivity, and bioimaging application, ACS Appl. Mater. Interfaces 4 (2012) 4387-4392.

[48] C. Cheng, H.-Y. Chen, C.-S. Wu, J.S. Meena, T. Simona, F.-H. Ko, A highly sensitive and selective cyanide detection using a gold nanoparticle-based dual fluorescencecolorimetric sensor with a wide concentration range, Sens. Actuators B 227 (2016)
$283-290$.

[49] C.-W. Wang, Y.-N. Chen, B.-Y. Wu, C.-K. Lee, Y.-C. Chen, Y.-H. Huang, H.T. Chang, Sensitive detection of cyanide using bovine serum albumin-stabilized cerium/gold nanoclusters, Anal. Bioanal. Chem. 408 (2016) 287-294.

[50] D. Lu, L. Liu, F. Li, S. Shuang, Y. Li, M.M.F. Choi, C. Dong, Lysozyme-stabilized gold nanoclusters as a novel fluorescence probe for cyanide recognition, Spectrochim. Acta A 121 (2014) 77-80.

[51] G. Zhang, Y. Qiao, T. Xu, C. Zhang, Y. Zhang, L. Shi, S. Shuang, C. Dong, Highly selective and sensitive nanoprobes for cyanide based on gold nanoclusters with red fluorescence emission, Nanoscale 7 (2015) 12666-12672.

[52] M. Shamsipur, H.R. Rajabi, Pure zinc sulfide quantum dot as highly selective luminescent probe for determination of hazardous cyanide ion, Mater. Sci. Eng. C 36 (2014) 139-145.

[53] A.A. Ensafi, N. Kazemifard, B. Rezaei, Label-free and turn-on fluorescent cyanide sensor based 2 on CdTe quantum dots using silver nanoparticles, RSC Adv. 5 (2015) 40088-40093.

[54] W.J. Jin, J.M. Costa-Fernández, R. Pereiro, A. Sanz-Medel, Surface-modified CdSe quantum dots as luminescent probes for cyanide determination, Anal. Chim. Acta 522 (2004) 1-8.

[55] Md.M. Rhaman, A. Alamgir, B.M. Wong, D.R. Powell, Md.A. Hossain, A highly efficient dinuclear $\mathrm{Cu}(\mathrm{II})$ chemosensor for colorimetric and fluorescent detection of cyanide in water, RSC Adv. 4 (2014) 54263-54267.

[56] Y. Dong, R. Wang, W. Tian, Y. Chi, G. Chen, "Turn-on" fluorescent detection of cyanide based on polyamine-functionalized carbon quantum dots, RSC Adv. 4 (2014) 3701-3705.

[57] E.Z. Lee, S.U. Lee, N.-S. Heo, G.D. Stucky, Y.-S. Jun, W.H. Hong, A fluorescent sensor for selective detection of cyanide using mesoporous graphitic carbon(IV) nitride, Chem. Commun. 48 (2012) 3942-3944.

[58] M. Devaraj, R. Saravanan, R.K. Deivasigamani, V.K. Gupta, F. Gracia, S. Jayadevan, Fabrication of novel shape $\mathrm{Cu}$ and $\mathrm{Cu} / \mathrm{Cu}_{2} \mathrm{O}$ nanoparticles modified electrode for the determination of dopamine and paracetamol, J. Mol. Liq. 221 (2016) 930-941.

[59] A. Umer, S. Naveed, N. Ramzan, M.S. Rafique, M. Imran, A green method for the synthesis of copper nanoparticles using L-ascorbic acid, Rev. Mater. 19 (2014) 197-203.

[60] X. Lou, L. Qiang, J. Qin, Z. Li, A new rhodamine-based colorimetric cyanide chemosensor: convenient detecting procedure and high sensitivity and selectivity, ACS Appl. Mater. Interfaces 11 (2009) 2529-2535.

[61] H. Cao, Z. Chen, H. Zheng, Y. Huang, Copper nanoclusters as a highly sensitive and selective fluorescence sensor for ferric ions in serum and living cells by imaging, Biosens. Bioelectron. 62 (2014) 189-195.

[62] L. Xiaoqing, L. Ruiyi, L. Zaijun, S. Xiulan, W. Zhouping, L. Junkang, Fast synthesis of copper nanoclusters through the use of hydrogen peroxide additive and their application for the fluorescence detection of $\mathrm{Hg}^{2+}$ in water samples, New J. Chem 39 (2015) 5240-5248.

[63] M. Fernández-Ujados, L. Trapiella-Alfonso, J.M. Costa-Fernández, R. Pereiro, A. Sanz-Medel, One-step aqueous synthesis of fluorescent copper nanoclusters by direct metal reduction, Nanotechnology 24 (2013) 495601-495606.

[64] J.R. Bhamore, S. Jha, A.K. Mungara, R.K. Singhal, D. Sonkeshariya, S.K. Kailasa, One-step green synthetic approach for the preparation of multicolor emitting copper nanoclusters and their applications in chemical species sensing and bioimaging, Biosens. Bioelectron. 80 (2016) 243-248.

[65] W. Wang, F. Leng, L. Zhan, Y. Chang, X.X. Yang, J. Lana, C.Z. Huang, One-step prepared fluorescent copper nanoclusters for reversible pH-sensing, Analyst 139 (2014) 2990-2993. 